\title{
'Bombora', 'MALABar Mansion': the psychogeography of the Sydney Sonic Sublime
}

\author{
Transforming Cultures eJournal, \\ Vol. 4 No 1 April 2009 \\ http://epress.lib.uts.edu.au/journals/TfC
}

\section{Peter Doyle $^{1}$}

\section{Abstract}

This paper looks at two recordings connected with the strangely disquieting tract of fifteen or so square miles separating the northern shores of Botany Bay from the Pacific Ocean, in Sydney's south-east. In 1964 the Atlantics, a band composed mainly of young migrant Australians produced a reverb-drenched guitar instrumental called "Bombora". The name - an Aboriginal word referring to a type of submerged rocky reef, over which large ocean waves occasionally and unexpectedly break - had immediate meaning to Sydney's surfer subculture. But for the population of the Botany Bay area, the term had a more local meaning, referring to one specific reef where, over the years, many boat fishermen, often migrants unused to the local conditions, had been killed. In the 1988 recording, "Malabar mansion," singer Mac Silver prepares himself for the horrors of a night in Long Bay Jail, (located nearby on that same peninsula). At that time a commission of inquiry was investigating the deaths in custody of large numbers of young Aboriginal prisoners, and Silver's recording had powerful political and emotional resonances. "Bombora" is a frenzied, almost operatic piece, and many listeners hear a bouzouki and folk dance influence in Theo Penglis's lead guitar. The chaotic textures, high pitch and fast pace might be heard as a musical analogue of hyperventilation and a racing heart beatbodily markers of the state where excitation becomes terror, leading to a moment of transcendence, a kind of sonic sublime. "Malabar Mansion", on the other hand is almost anti-sublime: quiet, literal, weary, precise in its delineation of the psychic and physical perils, and disarmingly specific in describing the elsewhere for which the singer longs. The peninsula whence these songs come has long been an uneasy presence in the city's imaginary, a combined badlands and seaside idyll. Over the past century suburban homes have shared the snakeinfested sandhills, heath, swamp with a leprosarium, a prison, a cemetery, a crematorium, a rubbish dump, a sewerage works, a power station, a rifle range, an army depot, tanneries, refineries, a migrant hostel, a shipping terminal and a sprawling post war housing project. Although rarely visited by tourists, the area has some of the most hauntingly beautiful coastline in the Sydney district, and is home to native flora and fauna long since lost to the rest of Sydney. Neither "Bombora" nor "Malabar mansion" simply "sounds like" the places they are meant to evoke, but both, I will argue, are thoroughly determined by moods,

\footnotetext{
${ }^{1}$ Peter Doyle lectures in writing and media studies at Macquarie University, Sydney.
} 
physical ecologies and insoluble contradictions of place.

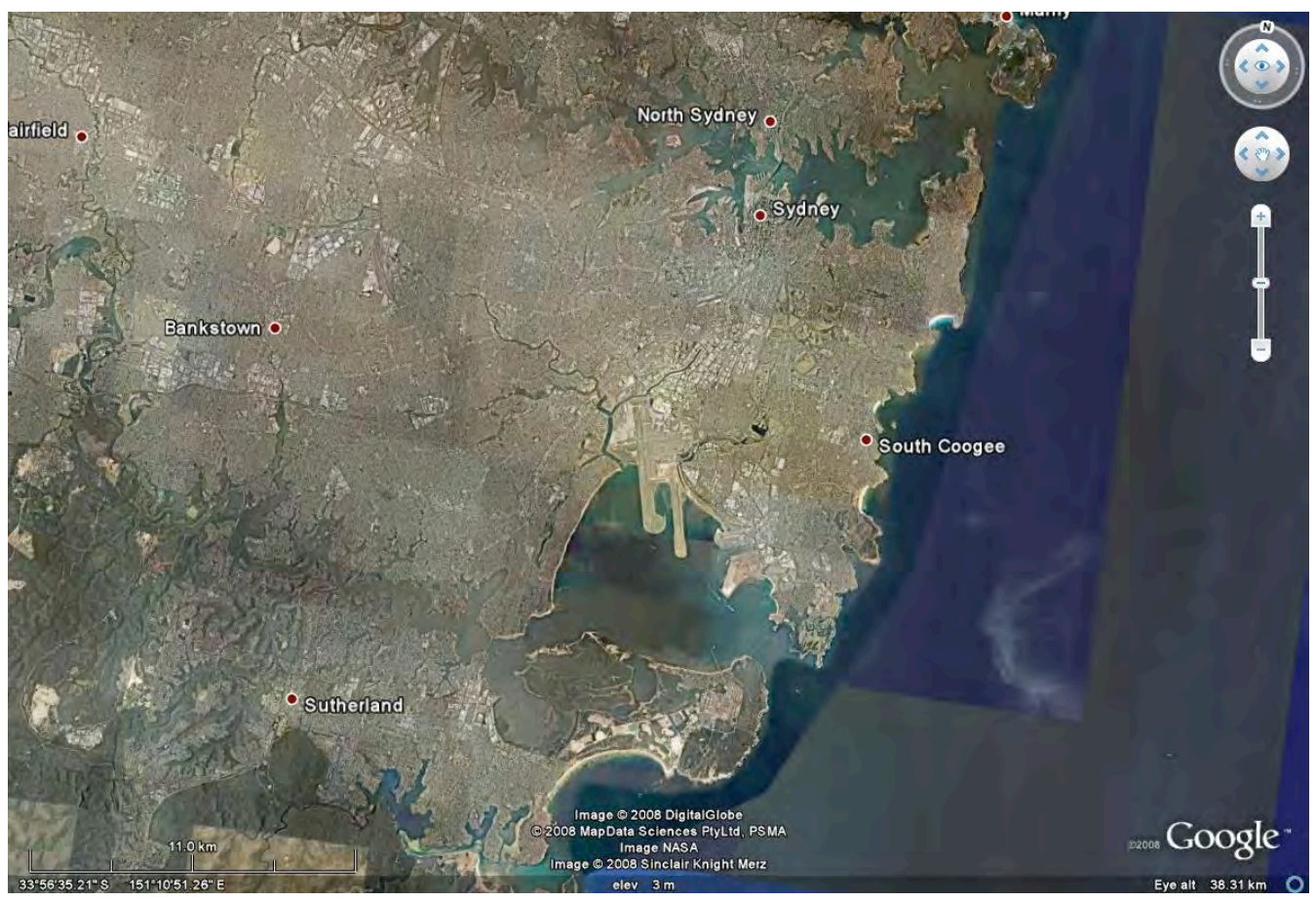

Figure 1. Google Earth image, Botany Bay and South Sydney

It is difficult to talk of popular music without making at least passing reference to place - to places of origin, places of consumption and the flows between them; to the many ways place might be referenced, explicitly or covertly in music; the effects place exerts on music and vice versa. We talk of place in the abstract and of specific places, of scenes, sounds and practices, of the intense local creative efflorescences which are so typical of twentieth century popular musics, and of local inflexions and hybrids. ${ }^{2}$ Then there are all the affiliations between recorded popular music and place, many of which are complex and subtle. Or contentious. A sub-, sub-category of all this is the exploration of the relationship of recorded music to strange, uncanny, unsettling, abject and deeply contradictory places, which is the territory into which this essay wanders.

The records in question are the surf instrumental 'Bombora', and the country song 'Malabar Mansion', each of which, in different ways, has connections to a strange, 20 or so square-kilometre zone in southern Sydney - the peninsula which separates the

\footnotetext{
${ }^{2}$ A good place to start exploring the relationships between music and place in Australia might be Connell and Gibson (2002). The literature - particularly histories -- of jazz, country music, blues, and world and 'roots' music in general is of course heavily suffused with notions, romances and mythologies, many egregiously erroneous, of place.
} 
northern shore of Botany Bay and the Pacific Ocean. The area includes the suburbs of Maroubra, Matraville, Malabar, Little Bay, Chifley, Mascot, Botany, Pagewood and La Perouse.

That area happens to be modern Australia's primal ground. The southern shore of Botany Bay is where Captain James Cook first raised the flag and claimed the east coast of Australia for Britain. So taken with the local flora and fauna was ship's naturalist Joseph Banks that Cook named the estuary Botany Bay. No one much after Banks, however, quite saw the charm of the place - the fleet sent out eighteen years later to set up a penal colony took one glance at the desolate windswept bay and kept going, 10 miles up the coast, to the more obviously picturesque Sydney Harbour. The convict colony expanded and retained the general name Botany Bay, however, and, for the early nineteenth century British underclasses, to find oneself "bound for Botany Bay" as a transported convict was the second worst luck you could have (the absolute worst being hanging).

The city of Sydney grew around the Harbour, and out to the west, but the sandy, swampy, treeless wastes around Botany Bay to the near south remained mostly uninhabited. "Botany" became the city's isolation zone: a rubbish dump, a leprosarium, an infectious diseases hospital, a sewerage works, a prison, a cemetery, a power station, tanneries and other noisome industries were put there. A Methodist mission for Aborigines was set up at the remotest part of the peninsula, La Perouse. Later there were chemical plants, military depots, housing projects, a shipping terminal, and half a dozen golf courses and of course the airport. During the Depression shanty towns and "happy valleys" appeared on the peninsula, and there were hermits and itinerants living out there in cliffside caves until quite recently, and perhaps still. There is nowhere else in the city of Sydney which so concentrates the unlovely and unwanted.

There is a narrow strip of National Park running along the ocean cliffs there now - it is quite stunningly beautiful, and surprising, and native fauna lost to the rest of Sydney survives there, but it is little visited; few power walkers are to be seen there. The vicinity rarely appears in the literature of Sydney, except in crime novels, ${ }^{3}$ and it is the one stretch of the Sydney coast which almost never gets used for film locations.

\footnotetext{
${ }^{3}$ See for example White Meat, Peter Corris, Sydney: Pan, 1981
} 
Gloomy views of the area however do keep turning up in my research into the Forensic Photography Archive, held at the Justice \& Police Museum. It is still a place where molesters take victims; and where killers dump bodies. It is Sydney gothic. ${ }^{4}$

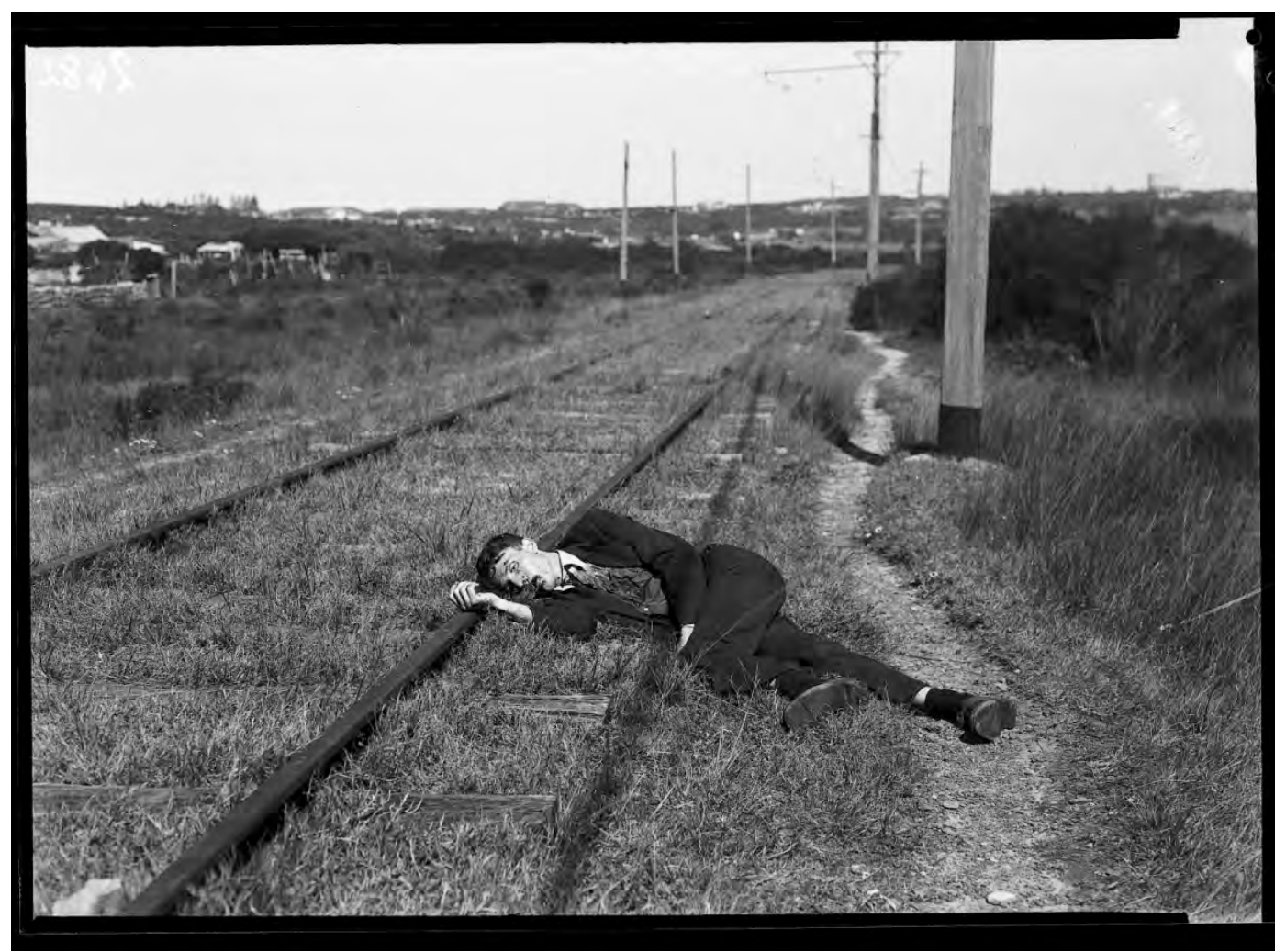

Figure 2. Homicide victim, circa 1938. Details unknown, but believed to be in the Malabar - Botany - Matraville area. Courtesy Forensic Photography Archive, Justice \& Police Museum, Sydney.

Yet for tens of thousands of post war Greek, Maltese, Italian, East European and Northern English migrants, and for working and lower middle class aspirationals, for the Koori people still living in La Perouse, it is generally regarded as not so bad a place. On the day I was born, my father put a deposit on a house in the suburb of Maroubra the last outpost of bungalow respectability before the wasteland to the south - and never to my knowledge regretted it.

\footnotetext{
${ }^{4}$ See for example,

$<$ http://collection.hht.net.au/firsthhtpictures/fullRecordPicture.jsp?recnoListAttr=recnoList\&recno=31190 $>$,

$<$ http://collection.hht.net.au/firsthhtpictures/fullRecordPicture.jsp?recnoListAttr=recnoList\&recno=31189 $>$ and

$<$ http://collection.hht.net.au/firsthhtpictures/fullRecordPicture.jsp?recnoListAttr=recnoList\&recno=31245 $>$.
} 
As children we took the windswept desolation of the sandhills, swamps, cliffs and construction sites for granted. At La Perouse there were boomerang throwers, and a snake man who did tricks with taipans and black snakes. (In keeping with its not-quiteright nature, there were a lot of snakes in the area). There was a derelict film studio near our house and next to it a fenced off melaleuca forest where it was believed a pirate ship was marooned in a man-made pond, a left-over, it was said, from the 1950 shooting of the Robert Newton film Treasure Island.

If there is a Sydney magic-realist, then this is it. Anything you say about the area, the opposite also holds. For most of the twentieth century the sewerage works at Malabar poured millions of gallons of untreated effluent into the Pacific Ocean. A plume of discoloured water stretched almost to the horizon, and great chunks of congealed fat and other matter washed up on Maroubra Beach. I learned recently that the tannery and abattoir waste in the effluent provided the biggest single southern hemisphere food source for the rare, usually solitary wandering albatross, large numbers of which made the sea of offal a major stop on their two yearly transglobal migrations. ${ }^{5}$

There is a natural and cultural variegation on the peninsula not found anywhere else in Sydney. Not in 1963, anyway, the year that a young guitar band from Maroubra calling themselves The Atlantics released their first single, an instrumental called 'Bombora', which quickly went to number one on the local charts and stayed there for many months. Bombora's mad tempo, tinny guitar lead, clicky tape echo and oceans of reverb place it squarely as surf instrumental. ${ }^{6}$

\section{Link to audio sample 1, 1: 30 secs of 'Bombora'}

[To hear these MP3 audio samples, please make sure you are reading the document using Adobe Reader 9. This is free and available online at <http://www.adobe.com/products/reader/>]

Before that record came out, the Atlantics were a solid draw at the surf club, scout hall, CYO (Catholic Youth Organisation) dances of the district. They were the local surf culture's band of choice, but they were not themselves of it: they were dark-haired lads,

\footnotetext{
${ }^{5}$ See Low, Tim (2002) The New Nature: Winners \& Losers in Wild Australia Sydney: Viking

${ }^{6}$ The record is still fondly remembered. In my experience as a working musician, I know that if one is to play any surf instrumental from around that time -- 'Pipeline', 'Wipeout', 'Miserlou', 'Walk Don't Run' Australians of a certain age will almost certainly identify it as 'Bombora'.
} 
of Greek and Slavic extraction - and this, it is sometimes said, accounts for Bombora's folk dance feel, and the bouzouki-like character of Theo Penglis and Jim Skiathitis's guitars. $^{7}$

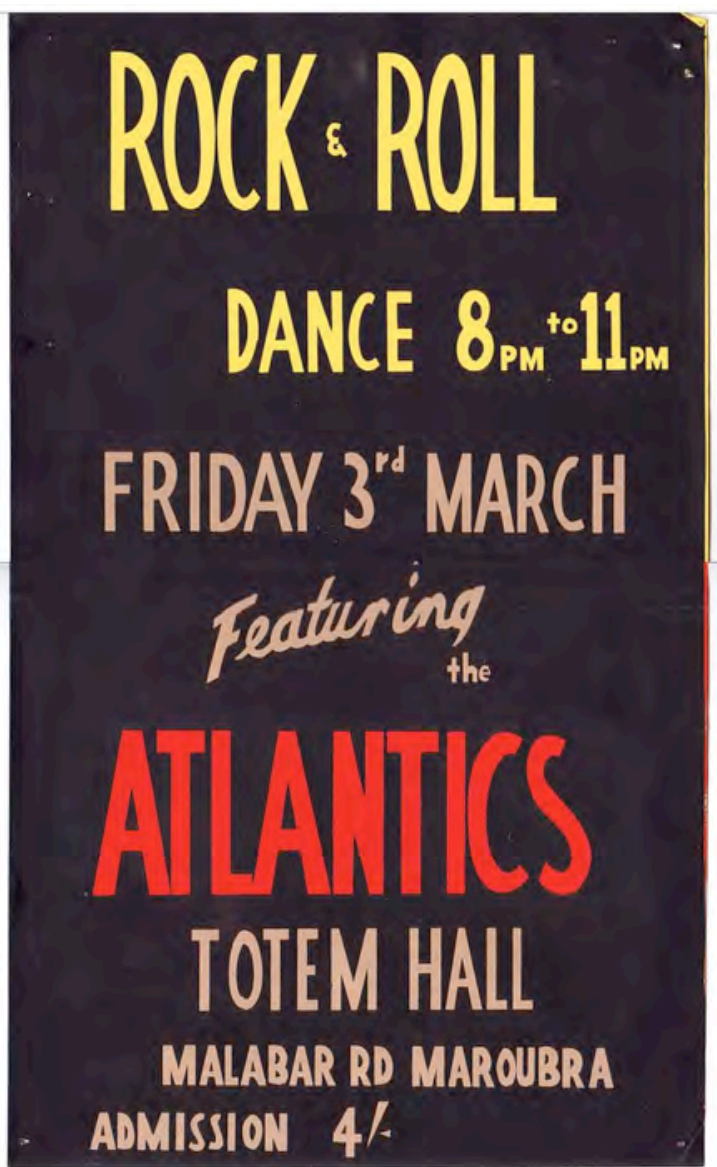

Figure 3. Early Atlantics dance poster. Courtesy Eddy Matzenik

Bombora was the first Australian pop song I'd ever heard which was explicitly about something local. The word 'bombora' refers to a rocky submerged reef, in still water, where large waves form up, hollow out and break without warning. In the early $60 \mathrm{~s}$, 'bombora' meant to me and to people in the area, one particular reef two hundred yards off Bare Island at La Perouse: a pretty, almost Mediterranean-looking spot where ocean fish sometimes gather in great numbers.

${ }^{7}$ As remarked upon by Billy Thorpe in his Sex and Thugs and Rock'n'roll (p101) and more recently by Jon Stratton, who points out that the band themselves "never acknowledged the possible Greek influence on their music, preferring to highlight that many Australians thought they were an American band..." (p11)

Interestingly, although I have heard numerous casual references made to the alleged Atlantics-Greek wedding band sound, I cannot recall ever hearing that said before the late 1980s - i.e. the "world music moment'. 


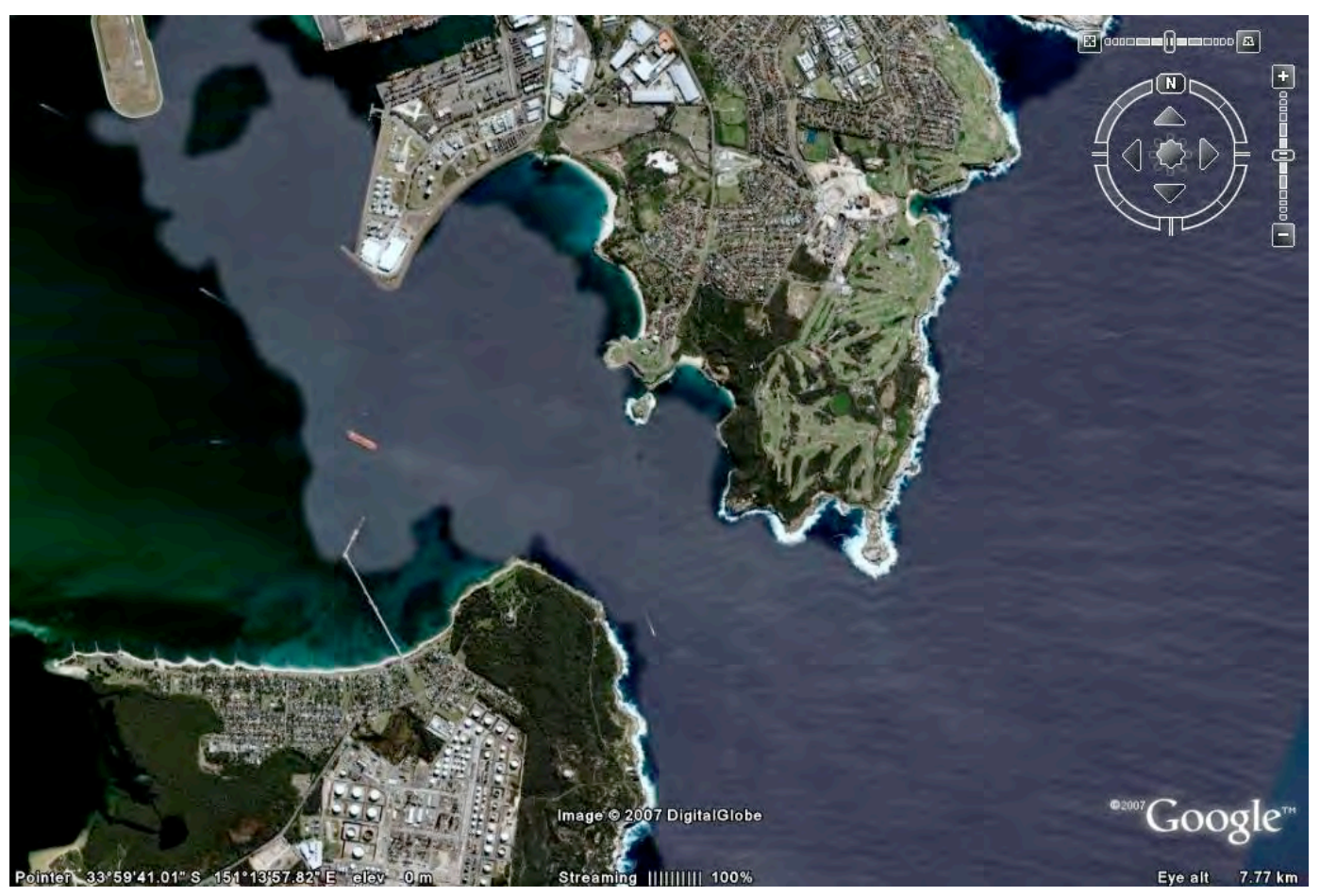

Figure 4. Google Earth image, accessed January 2007

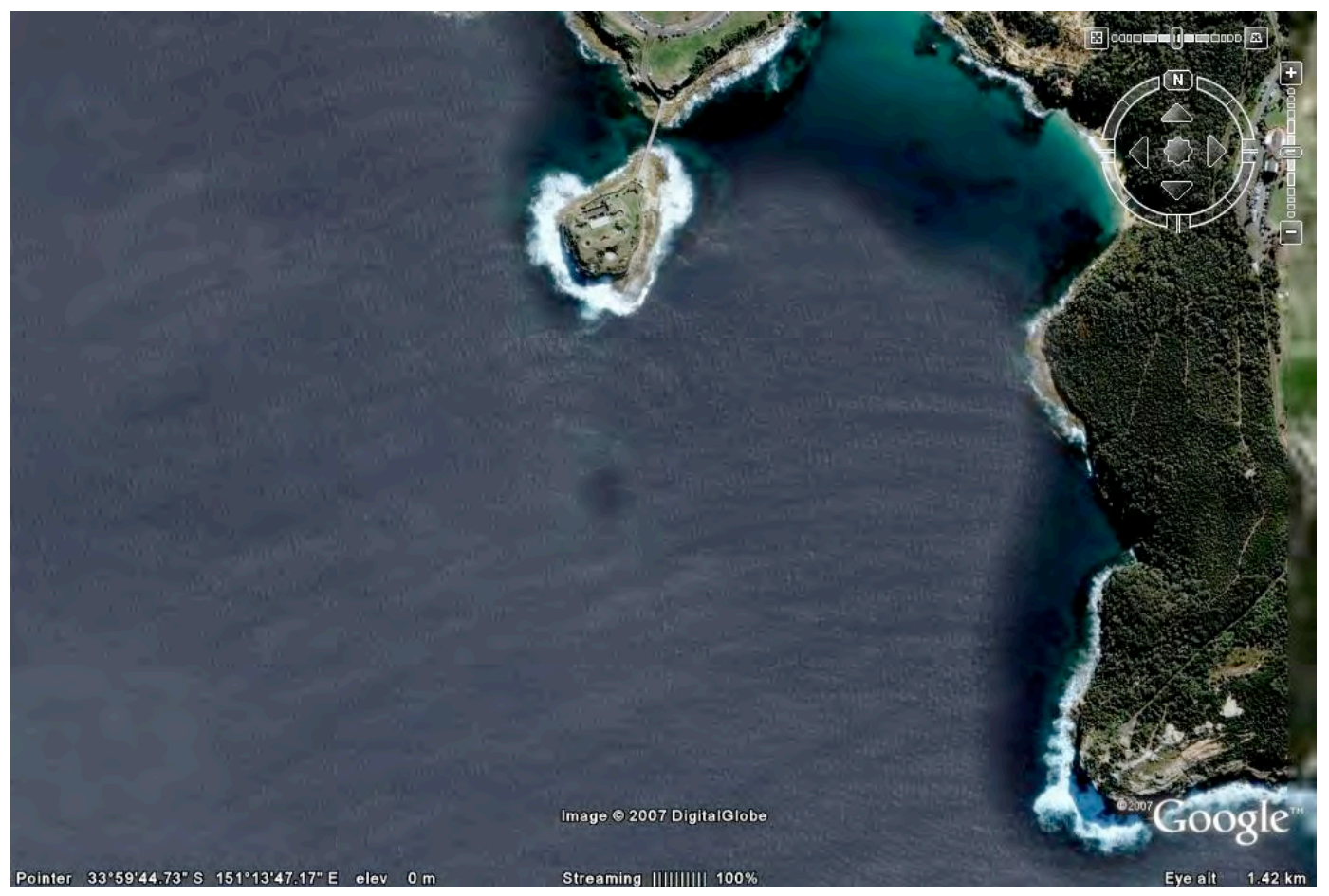

Figure 5. Google Earth image, accessed January, 2007. The dark spot in the centre of the image is the Bare Island Bombora 


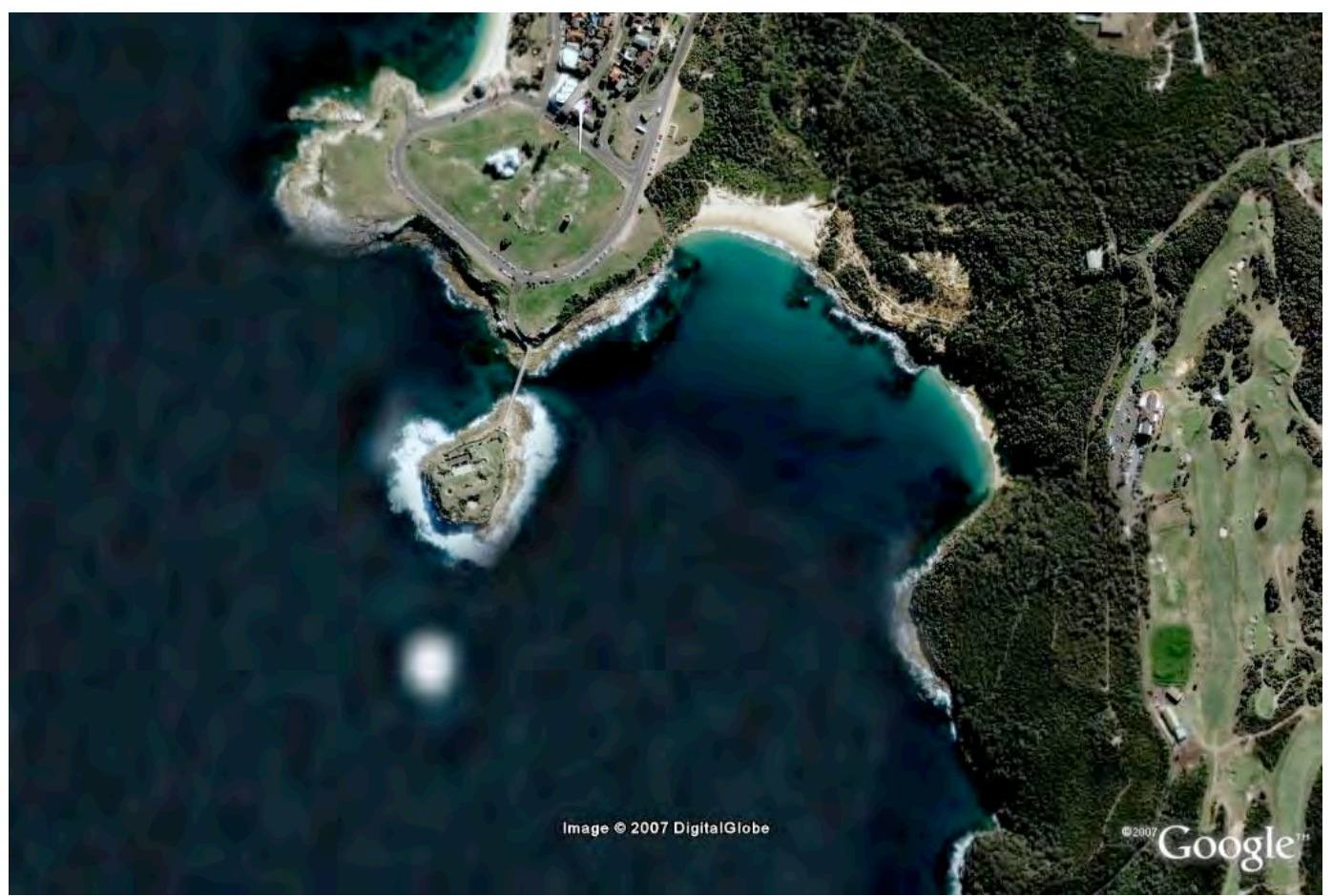

Figure 6. Google Earth image, accessed August 2007. A lower resolution image captures the bombora on a day when it is breaking

Botany Bay was and still is much beloved of boat fishermen, especially the large numbers of Greek and Maltese migrants who moved into southern Sydney suburbs in the 1940s and 1950s. As power boat ownership among migrants rose, so too did the death count at the Bare Island bombora. It became the Bermuda Triangle of Sydney waterways.

To the surfer culture on the south side the Bare Island bombora also became the mythic wave. The killer wave. The Matterhorn of the surf, and to this day there exists a local folklore about the bombora, and who first rode it. One place, with two quite distinct constellations of meaning, and a whiff of morbidity adhering to both.

I was originally intending to make a case at this point about migrancy, and how the outsider's more crystalline vision might refract the society in a way that the settled local never could. We would thus have the Atlantics speaking officially in the idiolect of their predominantly Anglo-Celtic surfer audiences, while secretly addressing a more specific local experience in a semi-underground language of ethnic retentions and ancestral forms. 
But I don't believe it is that simple. Or maybe it's more simple. Eddy Matzenik, the original bass player with the Atlantics accounts for Bombora's Levantine folk dance feel this way: the guitar teachers in Sydney then - there were two of them, basically routinely gave their students, including the schoolboy Atlantics, minor-key public domain folk tunes to learn - 'Dark Eyes', 'Greensleeves' and such. The Atlantics did not particularly play blues scales, not then anyway, because their teachers didn't teach them. But what about that wild dervish folk rhythm? Lifted straight from Buddy Holly's 'Peggy Sue', says Eddy. But the rembetika-bouzouki sound? Well, maybe (Eddy gets a little impatient) but lead guitarist Theo Penglis's parents owned a bakery and Theo was educated at the exclusive Sydney Grammar, and no one in the band was fresh off the boat, or anything like it. (Eddy himself is third generation Australian).

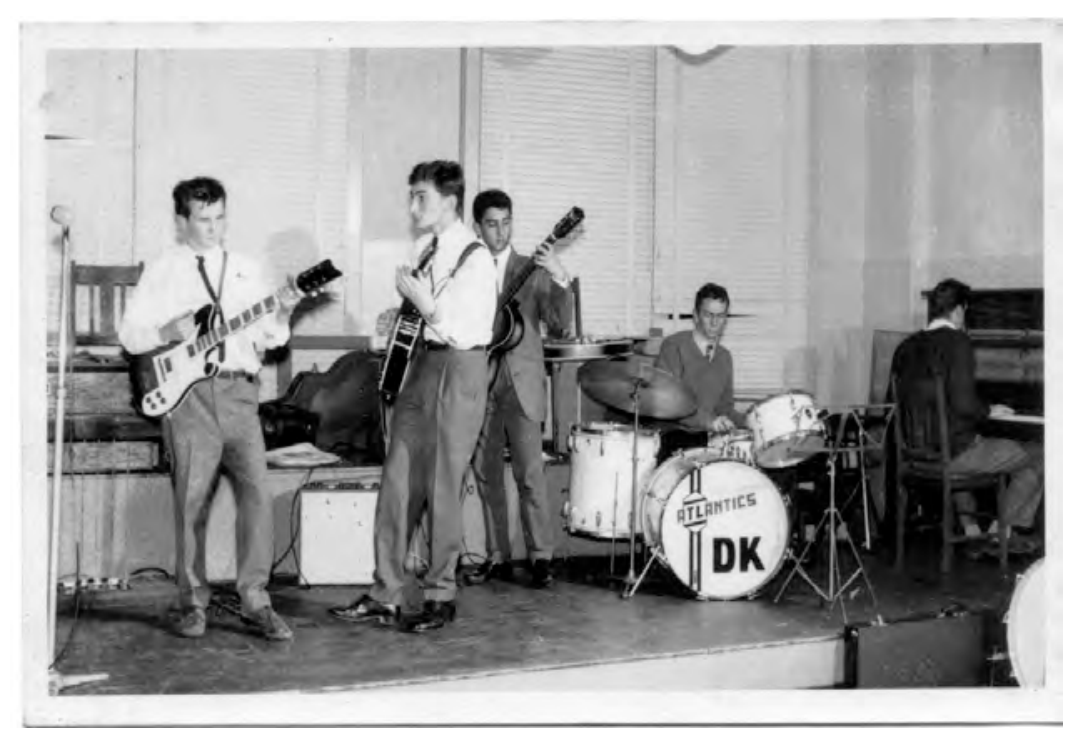

Figure 7. The young Atlantics. Photo courtesy Eddy Matzenik

A quick unpacking of what we hear: The Peggy Sue drum feel $=$ a human heartbeat in adrenalin overdrive, a symptom of exertion, exhilaration or fear. The reverb tells us we are near something big, sound reflecting physical mass, a mountain, a monument, a giant wave. The high pitch and minor key — danger, and more excitation. It all follows through to an orderly rather than chaotic resolution. Put it all together and we have a musico-sonic evocation of terror and transcendence - pop music's version of the romantic sublime. Teen opera, or maybe melodrama. Let's leave it for a moment.

Death is very literal and very near in 'Malabar Mansion', a song about Long Bay Gaol written by one Dave Duncan, a whitefella who did time there in the early 1980s. 


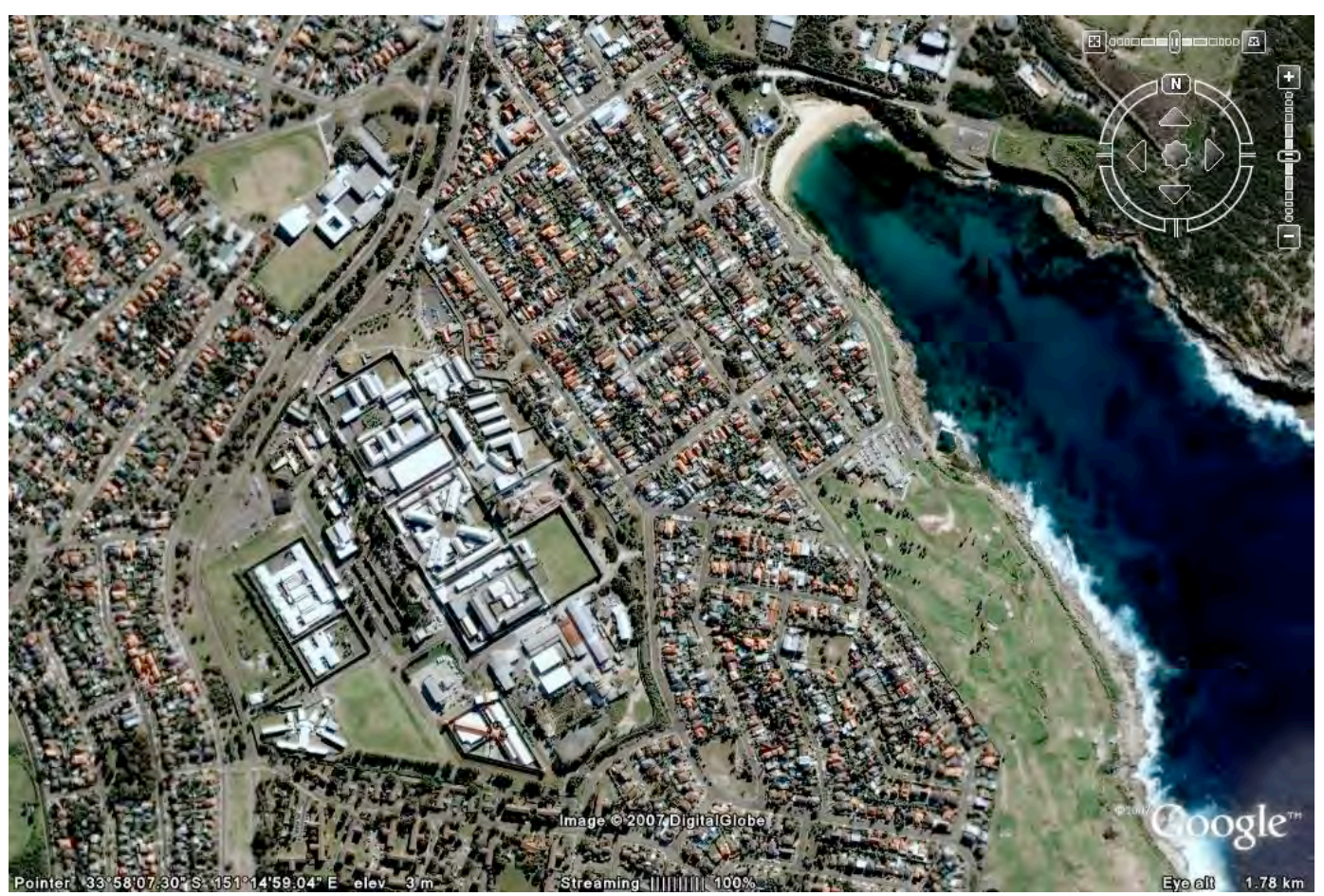

Figure 8. Google Earth image of Malabar and Long Bay Gaol, accessed January 2007.

Mac Silver, a blackfella, recorded the song in 1988 for an LP called Koori Classics: prison songs. 'Malabar Mansion' was released on the Enrec label, then coincidentally co-run by ex-Atlantic Eddy Matzenik, who plays steel guitar on this song.

Gaol songs do place in very particular ways: the fact of the narrator's confinement fixes him simultaneously in place, and utterly 'out of place', out of action, nowhere. Prison songs set up coordinates: the despised here of the cell and the longed-for elsewhere of the fancy dining car, the green, green grass of home, the arms of the beloved. Death, usually, is the only way to get there. 'Sing me back home before I die'. The prison cell thus recalls its monastic antecedent, where you consider your wrongs and prepare for death, as it does the locked psych ward, where you wrestle with insanity. The cell perhaps relates to the recording studio too, or more correctly, the recording studio invokes both its carceral and monastic antecedents. 


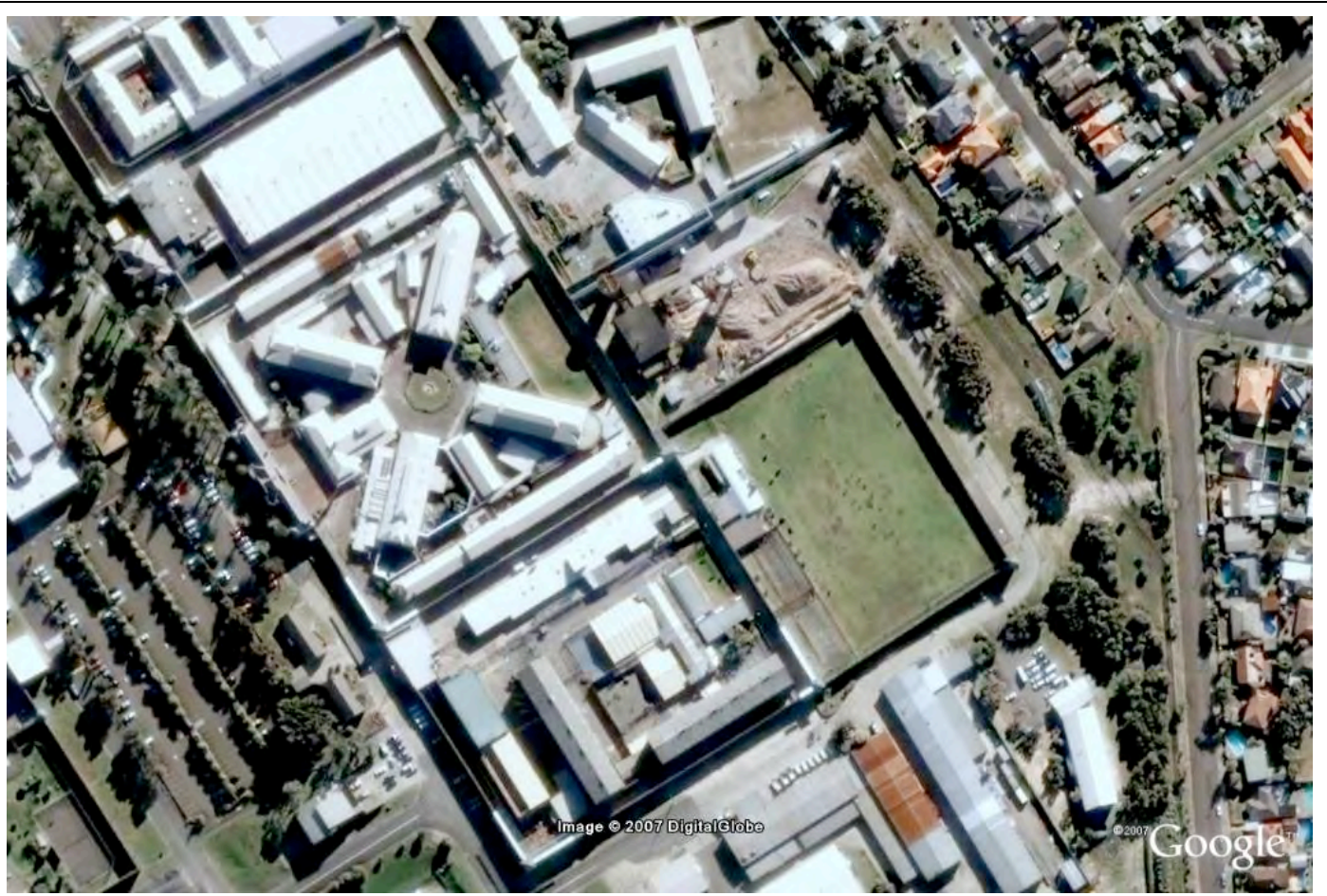

Figure 9. Google Earth image of Long Bay Gaol, accessed January 2007. Prisoners can be seen in the exercise yard, making them the objects of double or triple surveillance

'Malabar Mansion' departs from the prison song template a little. For one thing it's not a cautionary tale. There's no remorse for past sins. And the gaol here isn't merely generic. It's very specific. It's Long Bay Gaol, aka “the Bay”, Sydney's archetype for gaol. "Long Bay Gaol you're cruel and bad," sings Silver, in a quiet, relaxed, somewhat weary voice, "you have made sane men go mad, some have even took their lives at different times". The song gives us a particularly inside take on the quotidian. The evening ritual for example, is described in some detail:

\section{Link to audio sample 2 - from 'Malabar Mansion', 0:34sec}

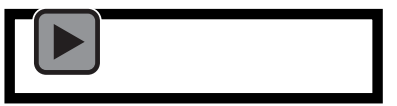

The screws slam doors hold [sic] the slots, he slips the bolts, snaps the locks/Some crims keep yelling out abuse at him. /Then it was lonesome time again, (I) had no books, had no pen/Waiting 16 hours to hear that big bell ring

This isn't gaol-as-metaphor-for-the-human-condition, this is real gaol "where the lifers think they're king", where the core suffering is boredom and isolation, where the greatest peril is suicide. (I am not aware of any other gaol song which mentions lack of reading and writing materials as a particular tribulation.) It's all so plainly stated, so personal yet matter of fact about the suffering it describes, that this recording can be hard to listen to sometimes. 
We come to the spoken middle, the fantasy of the desired elsewhere.

\section{Link to audio sample 3, 0:37sec}

I pace up and down my cell, I feel I've died and this is hell/ To stop me going mad I lay and think /Of my family in the scrub, and my pals back at the pub,/ And what's happening at Empy's where I drink

"Empy's" is a very inside reference: the Empress Hotel in Regent Street, Redfern, long since closed down, was for decades famous as one of the toughest pubs in inner Sydney. I'd never heard it called "Empy's" until I heard this song, however. It's one of those references by which a song really selects its audience.

The Koori Classics album recorded in 1988 was funded in part by a Federal government bicentennial grant. The concerted political campaign to raise awareness of Aboriginal deaths in custody had recently led to the establishment of a royal Commission, and emerging from that was the realisation that many of the deaths in custody were in fact suicides. There was a suicide epidemic going on.

Mac Silver, a blackfella, former drummer with Redfern band Black Lace had that year, 1988, been touring and performing in prisons and elsewhere with La Perouse-based excon and local hero Vic Simms, and there was a real convergence happening - the campaign over the high rates of Aboriginal incarceration was merging with agitation for social justice and land rights, and all that was overlapping with a wider interest in blackfella music. And there was an expectation that things would change, for the better. So the song came out of and was released into a charged contemporary context.

The last verse begins "My release ain't far away, I won't worry on that day" - he's talking about actual, not mystical release. There's transcendence on offer, though not of the romantic sublime sort. Hang in there, it says, you can get through your gaol time. And implicitly to its larger blackfella audience, hang in there, things can be better, and soon. For all its despair, 'Malabar Mansion' is hopeful. 
So, do songs "sound like" the places whence they come? Do they replicate or capture the cultural conditions of their manufacture? Obviously they do.

But recorded songs look forward and outward: to their prospective audience, to the market. To the future. They're appeals - prayers, even - to near posterity. They can't help but be about where they're from, but they're as much about where their makers and audiences are at the time, and where they're going, or want to go, or where they dread to go.

Recordings aren't sonic snapshots. They don't "freeze" a moment. They have duration and are about process. They're a microcosm of dynamic transition.

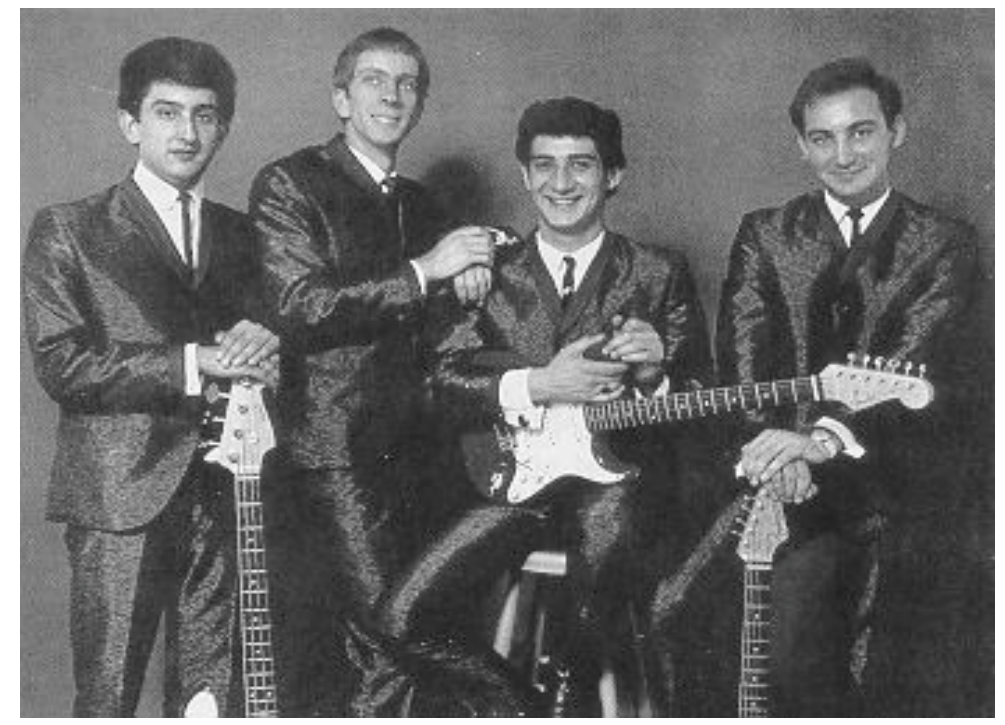

Figure 10. The Atlantics, c 1964, from <http://www.milesago.com/Artists/atlantics.htm>

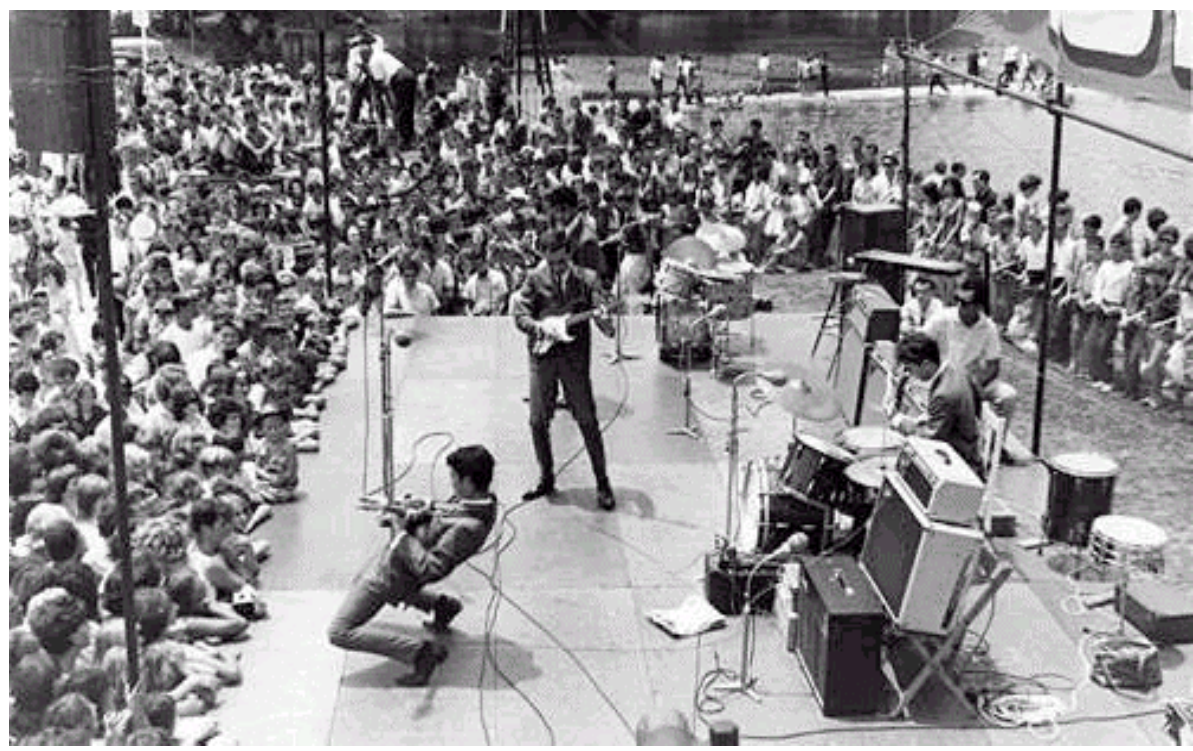

Figure 11. The Atlantics, c 1964. Image from <http://www.theatlantics.com> 
I $d o$ still hear the Greekness in the Atlantics. But they didn't play bouzoukis, there's no folk costumery there. They played Stratocasters, through new Fender amps. They wore pointy-toe boots and sharkskin suits. They don't lament. 'Bombora', with its tinny guitar sounds and CYO dance reverb seems quite perfectly emblematic of life in Maroubra, and in urban Australia then, and that was changing, quickly.

'Malabar Mansion' is outsider music, and doesn't try to be anything else. It's confined, and uncomfortably intimate in its exposition, but it too speaks to a hopeful future. Both songs traffic in aspirations, in desired elsewheres.

Both these recordings are figures on ground, a literal ground - with location, shape, history, materiality. That ground is also an object within psyche. The same psyche which in part is formed by that ground. These recordings stand in fluid relationship to their own past and their own future, and to a geography which is itself fluid. That is why pop records, some pop records, do time and place better and more truly than just about anything else can. They can't help it.

\section{Bibliography}

Connell, J. and Gibson, C. (2002) Sound Tracks: Popular Music, Identity, and Place, London: Routledge.

Corris, P. (1981) White Meat, Sydney: Pan.

Low, T. (2002) The New Nature: Winners \& Losers in Wild Australia Sydney: Viking.

Stratton, J. (2007) Australian Rock: Essays on Popular Music, Perth: Network.

Thorpe, B. (1996) Sex and Thugs and Rock'n'roll: a Year in Kings Cross, 1963-1964, Sydney: Macmillan. 